\title{
PENGEMBANGAN MEDIA PEMBELAJARAM GAME QUIZ UNTUK ANAK-ANAK USIA DINI MENGGUNAKAN APLIKASI ADOBE FLASH
}

\author{
Winia Waziana, Febriansyah \\ Jurusan Sistem Informasi, STMIK Pringsewu Lampung \\ Jl. Wisma Rini No. 09 pringsewu Lampung \\ Website: www.stmikpringsewu.ac.id \\ e-mail:winiawaziana@gmail.com_stmik_febriansyah@yahoo.com
}

\begin{abstract}
Abstrak
Perkembangan teknologi yang semakin pesat banyak perubahan dalam gaya hidup masyarakat. banyaknya penggunaan komputer, terutama untuk kehidupan sehari-hari. Para pengguna komputer berasal dari kalangan dan umur. Penggunaannya bisa berupa browsing, e-mail, bermain game, dan sebagainya. dengan game yang dikemas secara simple dan menarik bermanfaat sebagai media hiburan yang bersifat pembelajaran bagi anak-anak, serta dapat menjadi media alternatif bagi guru,dan orang tua dalam merangsang kerja otak anak serta menumbuhkan gairah anak untuk "belajar sambil bermain". Tujuan penelitian ini untuk menghasilkan aplikasi pembelajaran berbasis game. Penulis mengumpulkan data, melakukan pengamatan, melihat, dan menganalisa secara langsung kepada objek. Diawal game ini dijalankan langsung memunculkan game quiz memilih gambar yang benar sesuai dengan soal. Game ini diawali dengan halaman depan,terdapat tombol menu halaman2 sampai dengan halaman5 terdapat soal,dan halaman ke 6 hasil skor.
\end{abstract}

\begin{abstract}
Technological developments that intensified many changes in lifestyle community. the large number of computer use, especially for everyday life. Computer users come from circles and age. Its use can be browsing, e-mail, play games, and so on. with the games packaged in simple and interesting useful as a medium of entertainment that is learning for young children, and can be an alternative media for teachers, and parents in stimulating the brain works as well as cultivate a passion the children to "learn while playing". The purpose of this research is to produce a game-based learning applications. Authors gather data, conduct observations, view and analyze directly to the object. The beginning of the game run directly bring up games quiz choose the correct image in accordance with the problem. This game starts with the front page, there is a menu button halaman2 until Page 2 there is reserved, and the results page of the score.
\end{abstract}

Kata kunci: Pembelajaran, Game Quiz, Untuk Anak-Anak Usia Dini. 


\section{PENDAHULUAN}

\subsection{Latar Belakang}

Perkembangan teknologi yang semakin pesat saat ini telah membuat banyak perubahan dalam gaya hidup masyarakat. Salah satu perubahannya adalah banyaknya penggunaan komputer, terutama yang berbasis widows untuk kehidupan sehari-hari. Para pengguna komputer berasal dari berbagai kalangan dan umur. Penggunaannya bisa berupa browsing, $e$ mail, bermain game, dan sebagainya.

Seiring berkembangnya teknologi saat ini seharusnya bisa dimanfaatkan dengan tepat karena dengan memanfaatkan teknologi bisa membantu dan memudahkan dalam berbagai hal terutama dalam hal belajar. Belajar tentang teori pun akan membuat cepat bosan mereka. Pada masa anak-anak daya tangkap sangat tinggi, yang dimana mampu mengingat $20 \%$ dari yang dilihat dan $30 \%$ dari yang didengar. Dan orang mengingat $50 \%$ dari yang dilihat dan didengar serta $80 \%$ dari yang dilihat, didengar dan dilakukan [1]. Sehingga diperlukan sebuah sarana pembelajaran yang bisa memaksimalkan daya tangkap anak untuk membantu anak belajar dengan cara melihat, mendengar dan melakukan. Salah satu teknologi yang terus berkembang pesat dan dianggap bisa memberikan pembelajaran yang menyenangkan adalah dengan melibatkan game, karena game mengabungkan antara media lagu, teka teki dan permainan sehingga pembelajaran menjadi lebih menyenangkan.

Game sangat bermanfaat jika dimanfaatkan secara positif, seperti game yang berfungsi sebagai sebuah media edutainment yaitu media yang menggabungkan unsur edukasi (education) dengan hiburan (entertainment) atau sering disebut bermain sambil belajar. maka peneliti tertarik membangun sebuah game edukasi pembelajaran anak usia dini (calistung) berbasis Android. Di Indonesia sendiri, sistem operasi Android telah menjadi sistem operasi paling populer dengan persentase pengguna Android sekitar $52 \%$.

\subsection{Rumusan Masalah}

Berdasarkan latar belakang diatas dapat dirumuskan masalah yaitu bagaimana membangun sebuah aplikasi pembelajaran anak-anak usia dini menggunakan Adobe Flash?

\subsection{Manfaat Dan Tujuan Penelitian}

Dengan game yang dikemas secara simple dan menarik diharapkan dapat bermanfaat sebagai media hiburan yang bersifat edukatif bagi anakanak, serta dapat menjadi media alternatif bagi guru, pengajar dan orang tua dalam merangsang musikalitas anak serta menumbuhkan gairah anak untuk "belajar sambil bermain" sejak dini secara menarik, menyenangkan, efektif sehingga sang anak tetap mendapatkan keceriaannya saat belajar. Tujuan penelitian ini adalah untuk menghasilkan aplikasi pembelajaran berbasis game.

\section{LANDASAN TEORI}

\subsection{Game}

Menurut Ernest Adams dan Andrew Rollings dalam buku Fundamentals of game design, game merupakan salah satu jenis kegiatan bermain dengan pemainnya berusaha meraih tujuan dari game tersebut dengan melakukan aksi sesuai aturan dari game tersebut.

\subsection{Adobe Flash}

Adobe Flash adalah salah satu produk/software dari Adobe (dahulu bernama Macromedia sebelum dibeli oleh perusahaan Adobe) yang digunakan untuk proses membuat dan mengolah animasi atau gambar yang menggunakan vektor untuk skala ukuran kecil. Dahulu Software ini penggunaanya ditujukan untuk membuat animasi atau aplikasi yang bersifat online (menggunakan koneksi internet) ,namun seiring dengan perkembanganya Adobe Flash digunakan untuk membuat animasi atau aplikasi yang bersifat offline(tidak menggunakan koneksi internet).File yang dihasilkan dari Software ini menggunakan ekstensi .swf serta dapat di play atau diputar melalui Browser/Web dengan syarat sudah terinstall plugin Adobe Flash.

Bahasa pemrogramman yang digunakan di Adobe Flash menggunakan bahasa Action Script. Umumnya banyak yang menggunakan Action Script 2.0(ditujukan untuk penggunaan platform desktop) dan Action Script 3.0 (ditujukan untuk penggunaan platform mobile).

\subsection{Media Pembelajaran}

Menurut Supriatna, D., (2009). Pengenalan Media Pembelajaran. Hal 3 dan 4, media pembelajaran adalah sebuah alat yang berfungsi untuk menyampaikan pesan pembelajaran. Penggunaan media dalam pembelajaran dapat membantu anak dalam memberikan pengalaman yang bermakna bagi siswa. Penggunaan media dalam pembelajaran dapat mempermudah siswa dalam memahami sesuatu yang abstrak menjadi lebih konkrit.

\section{METODE PENELITIAN}

\subsection{Metode Pengumpulan Data}

\section{a. Observasi}

Dalam penelitian ini penulis melakukan observasi berupa melakukan pengamatan, melihat, dan menganalisa secara langsung kepada objek yang sedang berjalan. Masalah yang digunakan dalam penelitian yaitu kurangnya minat anak - anak sampai dengan remaja. 


\section{b. Wawancara}

Dalam wawancara yang dilakukan yaitu terhadap beberapa anak-anak mengenai bagaimana pendapat dengan adanya suatu pengembangan metode pembelajaran tentang game quiz happy fun serta menjelaskan tentang kelebihan dan kekurangan metode ini untuk merepresentasikan apa saja yang penulis buat.

\section{c. Studi Pustaka}

Penulis mengutip pendapat dan landasan dari beberapa sumber Jurnal, Proseding, Buku, dan Kajian-kajian yang mendukung dalam proses penyusunan karya ilmiah.

\subsection{Metode Pengembangan Sistem}

Dalam pengembangan Aplikasi ini menggunakan Sistem yang di rancang ini menggunakan metode Linear Sequential Model, model ini adalah melakukan pendekatan secara sistematis dan urut mulai dari level kebutuhan sistem lalu menuju ke tahap analisis, desain, coding, testing / verification, dan maintenance. Disebut dengan waterfall karena tahap demi tahap yang dilalui harus menunggu selesainya tahap sebelumnya dan berjalan berurutan. Berikut ini adalah tahap-tahap metode pengembangan SDLC adalah sebagai berikut: (Kristianto, 2004)

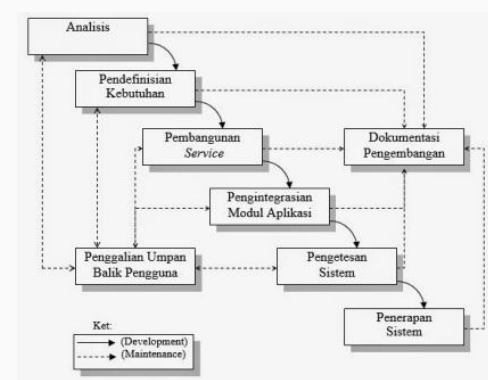

Gambar 1. Model Pengembangan Sistem adaptasi dari Agile SDLC Model

\section{PERANCANGAN DAN IMPLEMENTASI}

\subsection{Perancangan Flowchart}

Pembuatan game merupakan suatu kegiatan awal dalam mendesain sebuah game. Pembuatan game ini dapat dilakukan dengan model yang berbeda-beda. Game ini bersifat single player.

Berikut rincian game yang dibuat:

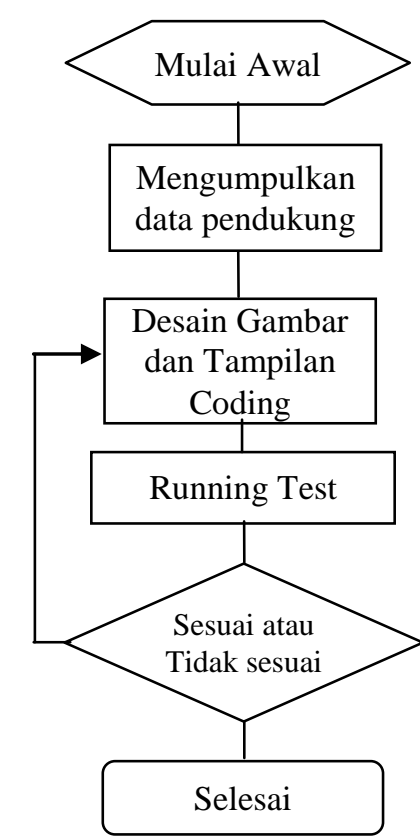

Gambar 2. flowchart langkah awal pembuatan game.

\subsection{Implementasi}

\section{Proses Pembuatan}

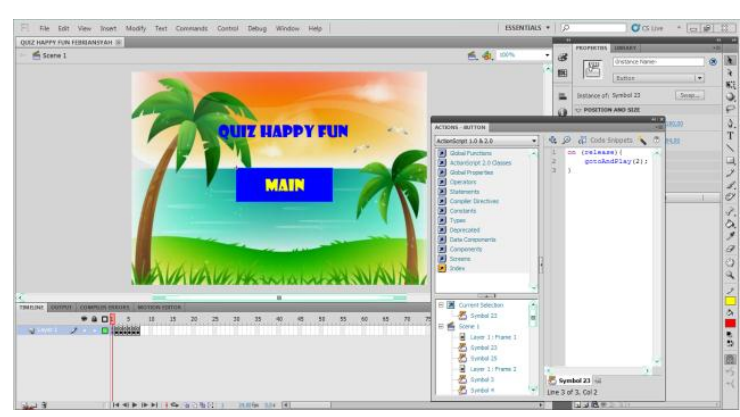

Gambar 3. Proses Pembuatan.

Halaman ini adalah proses pembuatan desain dan coding.

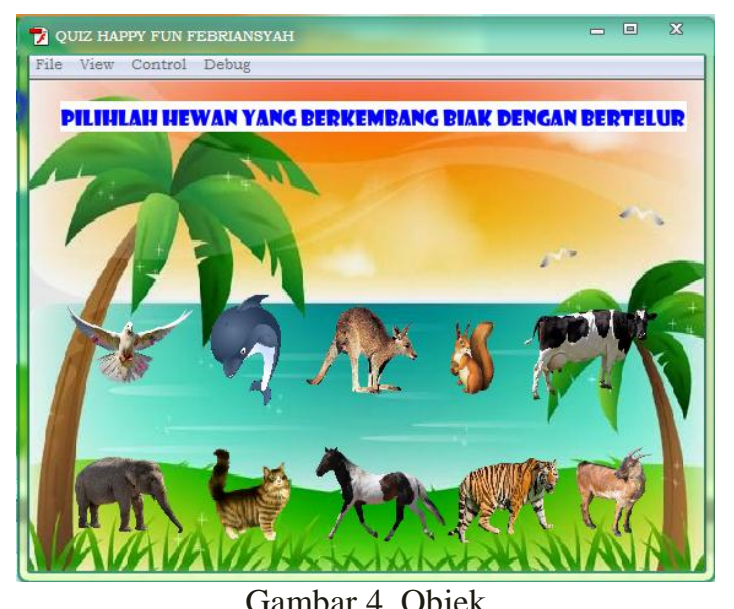

Halaman ini adalah pemain memilih jawaban dengan cara mengeklik gambar yang benar,dan mendapatkan skor. 


\subsection{Hasil Implementasi}

Diawal game ini dijalankan akan langsung memunculkan game quiz memilih gambar yang benar sesuai dengan soal. Game ini diawali dengan halaman depan,terdapat tombol menuhalaman 2 sampai dengan halaman 5 terdapat soal,dan halaman ke 6 adalah hasil skor. Berikut hasil implementasinya:

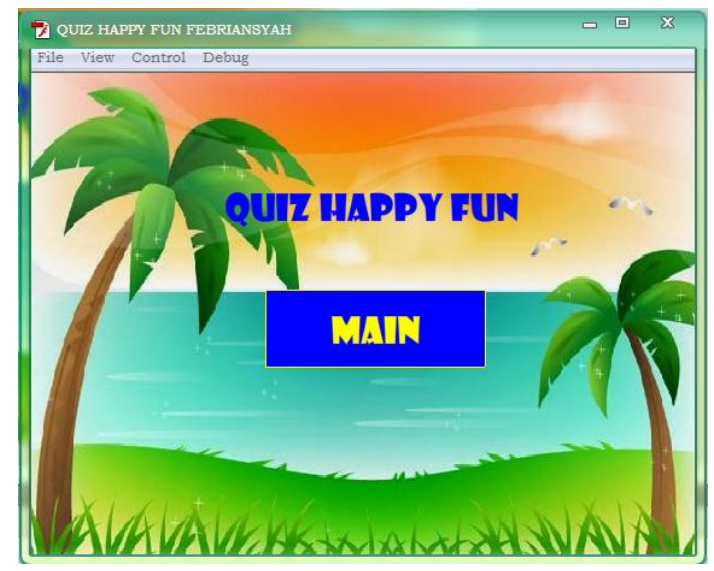

Gambar 5. Halaman Depan.

Halaman ini berisi tombol main untuk memulai permainan quiz happy fun.

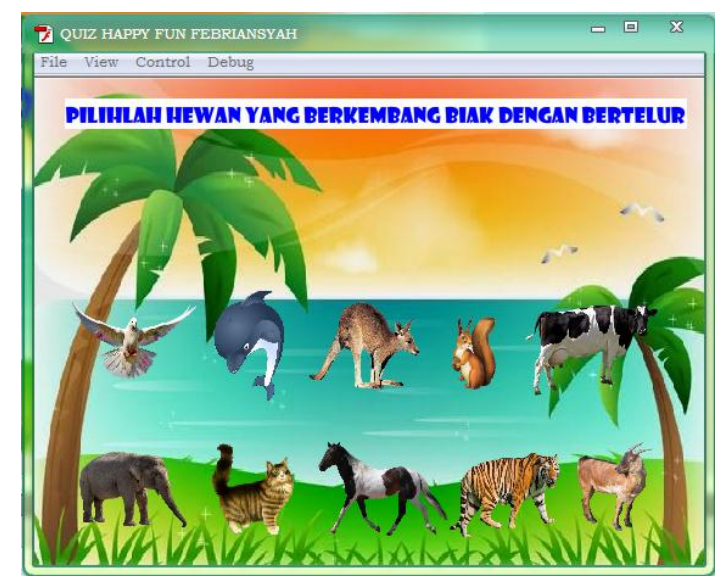

Gambar 6. Halaman soal 1

Pemain dianjurkan memilih jawaban yang tepat dengan mengeklik gambar yang benar,jika jawaban pemain benar maka mendapat nilai++,kemudian otomatis menuju soal berikutnya.

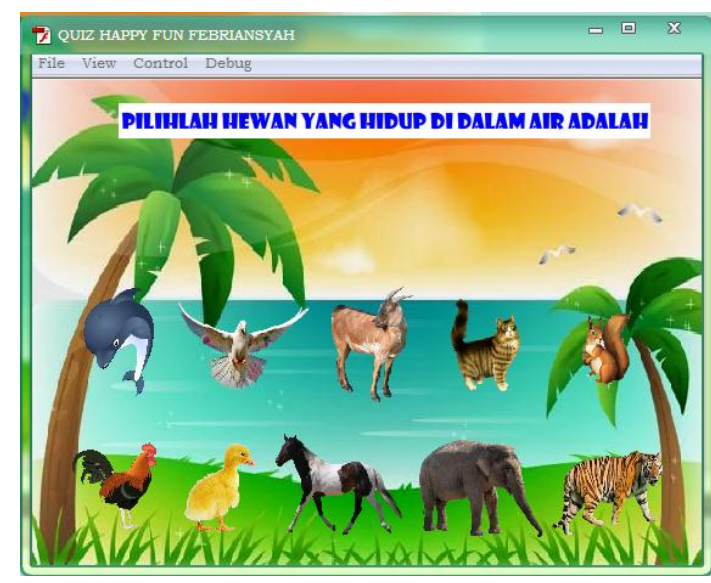

Gambar 7. Halaman soal 2.

Halalman ini sama seperti halaman pertama yaitu memilih jawaban yang benar dengan mengeklik gambar hewan yang benar, jika benar mendapat nilai++,kemudian otomatis menuju soal berikutnya.

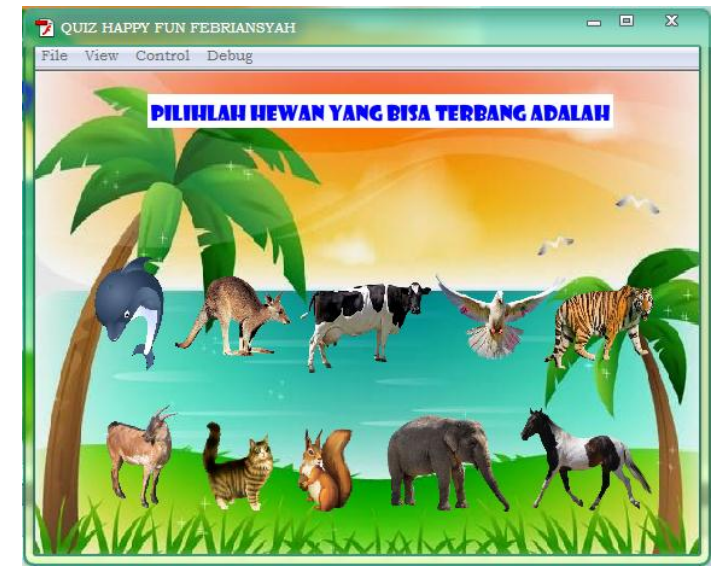

Gambar 8. Halaman soal 3

Halalman ini sama seperti halaman sebelumnya yaitu memilih jawaban yang benar dengan mengeklik gambar hewan yang benar, jika benar mendapat nilai++,kemudian otomatis menuju soal berikutnya.

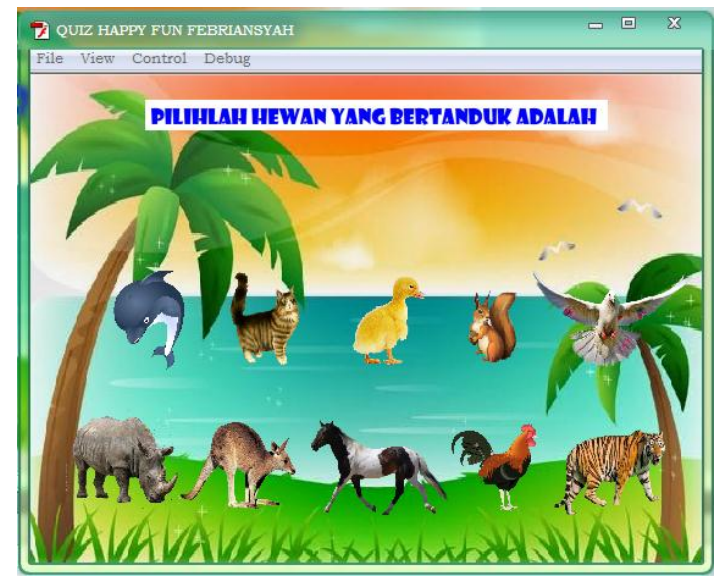

Gambar 9. Halaman soal 4

Halalman ini sama seperti halaman sebelumnya yaitu memilih jawaban yang benar dengan 
mengeklik gambar hewan yang benar, jika benar mendapat nilai++,kemudian otomatis menuju soal berikutnya.

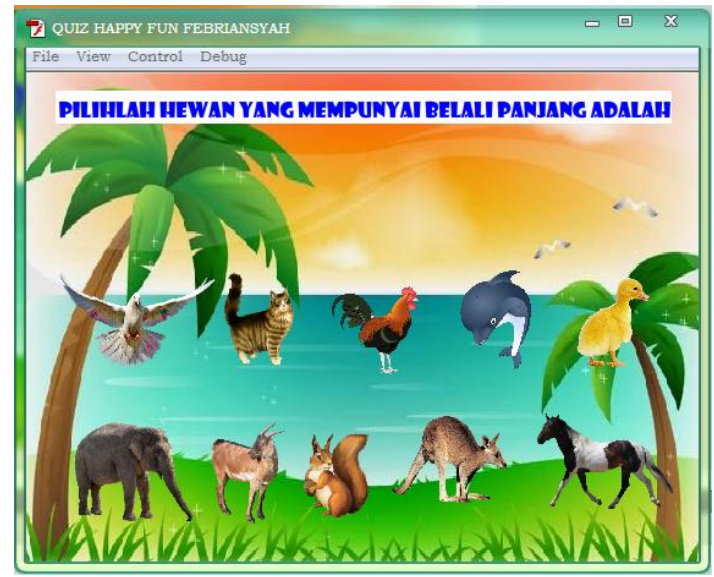

Gambar 10. Halaman soal 5

Halalman ini sama seperti halaman sebelumnya yaitu memilih jawaban yang benar dengan mengeklik gambar hewan yang benar, jika benar mendapat nilai++,kemudian otomatis menuju soal berikutnya.

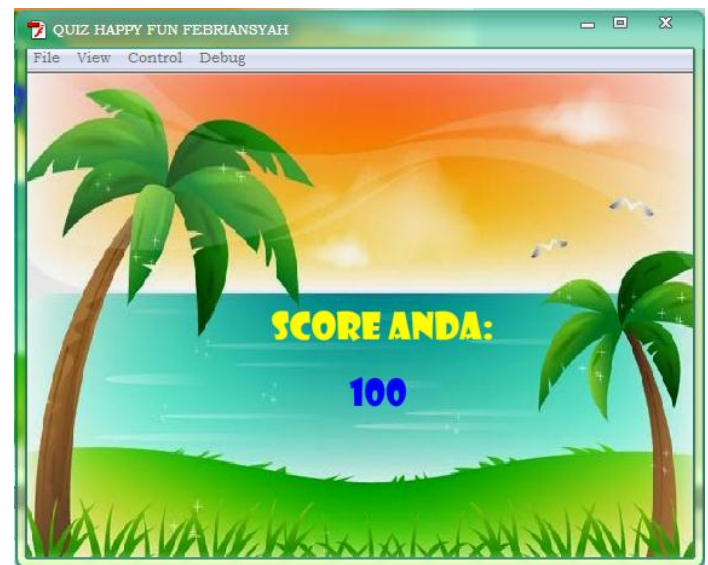

Gambar 11. Hasil

Jika pemain menyelesaikan semua soal dengan benar maka pemain mendapatkan nilai sempurna yaitu nilai 100 .

\section{KESIMPULAN}

Dari hasil pembahasan mengenai game pembelajaran quiz happy fun dapat disimpulkan bahwa game ini sangat ringan, mudah untuk dimainkan anak-anak, mengasah kemampuan pola pikir, dan tampilan menarik.

\section{DAFTAR PUSTAKA}

Abdul Hamid, Muhamad Muslihudin, 2016. Sistem Pedukung Keputusan Menentukan tingkat kualitas kesejahteraan Masyarakat Berdasarkan Indikator Badan koordinasi Keluarga Berencana Nasional
Menggunakan Web Mobile (Studi Kasus Desa Kutawaringin). TEKNOSI, Vol. 03, No. 02, Desember 2016. Hal. 57-66. Universitas Andalas. Sumatra Barat.

Agustina Candra, Wahyudi Tri (2015) Aplikasi Game Pendidikan Berbasis Android Untuk Memperkenalkan Pakaian Adat Indonesia vol 1 no 1.

Iskandarsyah, Yoda. (2012) "Pembangunan Game edukasi IPA untuk kelas 4”. Universitas Komputer Indonesia : Bandung.

Kurniawati, S., Calvin, dan Yustina, M, (2012) Pengembangan aplikasi pembelajaran bahasa inggris secara self-lerning pada sistem operasi android, skripsi s1

Nanan, Rohman Jurnal Sistem Informasi Membangun Aplikasi Game Edukatif Sebagai Media Belajar Anak-Anak, Stmik Mardira Indonesia, Bandung.

http://metodepengembangansistem.blogspot.co.id/2 015/02/agile-sdlc-system-development-life.html di akses pada Hari Jum'at 3 Maret 2017. 
